\title{
Perencanaan Dan Pengelolaan Keuangan Bumdes Desa Mendalo Darat, Kecamatan Jambi Luar Kota, Kabupaten Muaro Jambi
}

\author{
Mukhzarudfa, Wirmie Eka Putra, Afrizal, Susfayetti, Yuliusman \\ Program Pascasarjana, Program Magister Ilmu Akuntansi
}

\begin{abstract}
ABSTRAK
Pembangunan dan perkembangan BumDes menunjukkan bahwa masalah perencanaan dan pengelolaan keuangan, disamping masalah-masalah produksi, pemasaran dan kepegawaian merupakan masalah senteral Bumdes dalam usaha mencapai tujuan Bumdes. Badan Usaha Milik Desa (BUMDes) di Kabupatn Muara Jambi telah mencapai 149 unit, berarti sudah 149 desa yang membentuk BumDes, dan jumlah BumDes yang aktif sudah berada di 50 desa. Desa Mendalo Darat, Kabupaten Muaro Jambi udah memiliki Bumdes sejak tahun 2015 yang diberinama BUMDes Mendalo Jaya. Kegiatan yang dilakukan oleh BumDes Mendalo Jaya dalam tahun 2020 ini adalah kegiatan dalam bentuk jasa, yang meliputi: jasa pembayaran rekening listrik, telepon/speedy, angsuran motor/mobil, TV, PDAM, BPJS dan ATK. Masih terbatasnya kegiatan BumDes, dikarenakan masih terbatasnya investor yang mau melakukan investasi dan sumberdaya yang profesional dalam mengelola BumDes. Dari berbagai kegiatan yang sudah dilakukan BUMDes belum membuat atau menyusun perencanaan ataupun penganggaran. Kegiatan masih bersifat insidentil. Hasil dari kegiatan pengabdian yang telah dilakukan, diharapkan bagi aparatur pengelola BUMDes khususnya, memilki pengetahuan yang lebih baik dalam menyusun perencanaan dan pengelolaan keuangan BumDes.Secara spesifik luaran dari kegiatan pengabdian ini adalah: (1) Meningkatnya pengetahuan aparat BUMDes dalam membuat, menysusn perencanaan dan pengelolaan keuangan, sehingga dapat meningkatkan kinerja BUMDes. (2) Aparat BUMDes dapat menyusun rencana penjualan, rencana produksi, rencana biaya, baik itu rencana biaya produksi, rencana biaya bahan baku, tenaga kerja dan lain. Perencana kas, perencanaan piutang. (3) Dapat disusun laporan keuangan BumDes yang sesuai dengan standar yang ditetapkan oleh pemerintah.
\end{abstract}

Keywords: Perencanaan Keuangan, Pengelolaan Keuangn, Kinerja Bumdes, Desa Mendalo Darat.

\section{PENDAHULUAN}

Pembangunan dan perkembangan Bumdes menunjukkan bahwa masalah perencanaan dan pengelolaan keuangan, disamping masalah-masalah produksi, pemasaran dan kepegawaian merupakan masalah senteral Bumdes dalam usaha mencapai tujuan Bumdes.

Fungsi perencanaan dan pengelolaan keuangan tidak dapat dipisahkan dengan fungsifungsi lainnya di dalam perusahaan. Kegagalan dalam mendapatkan dana misalnya akan dapat menghambat pembelian bahan mentah yang selanjutnya dapat menghambat produksi. Hambata terhadap produksi akan berpengaruh terhadap pemasaran dari produksinya. Kurangnya dana dapat berpengaruh terhadap kemampuan perusahaan untuk dapat menarik tenaga akhli yang cakap. Kurangnya danapun akan dapat menghabat kegiatan penjualan perusahaan. Dengan singkat dapat dikatakan bahwa masalah pengeolaan keuangan erat hubungannya denan masaah-masallah pembelian, produksi, penjualan, personel dan masalah lain yang penting di dalam perusahaan. 
Perencanaan dan Pengelola keuangan pada awalnya hanya berurusan dengan masalah berapa besarnya dana yang diperlukan oleh bumdes dan kemudian juga bertanggungjawab untuk mendapatkan dana tersebut. Dalam sistem praktik akuntansi dan pengelolaan keuangan yang baru, segala kegiatan perencanaan dan pengeola keuangan dihadapkan kepada persoalan-persoalan fundamental mengenai operasi bumdes, yaitu: (1) berapa besar bumdes seharusnya, dan berapa kecepatan pertumbuhannya, (2) dalam bentuk apa aktiva aktiva harus dipertahankan oleh bumdes (3) bagaimana komposisi hutang-hutang yang seharusnya. (J.F. Weston dan E.F. Bringham, 2010).

Secara keseluruhan dapat dikatakan bahwa perencanaan dan pengelolaan keuangan dalam perkembangannya telah berubah dari studi yang terutama bersifat diskriptif menjadi studi yang terutama bersangkutan dengan teknologi informasi serta segala usaha mendapatkan dana menjadi bidang yang meliputi penggunaan atau alokasi dana, pengelolaan dari aktiva dan penilaian bundes di dalam pasar keseluruhan, dari bidang yang menekankan pada analisis eksteren perusahaan menjadi bidang yang menekankan pada pengambilan keputusan di dalam bumdes. (J.C. Van Horne, 2012).

Perencanaan dan Pengelola keuangan dalam perjalanannya harus mengambil berbagai keputusan keuangan. Keputusan yang perlu diambil pada dasarnya dapat dibagi menjadi tiga. Pertama, berapa jumlah dana yang diperlukan untuk setiap periodenya. Kedua, bagaimana kelebihan penghasilan bumdes akan diinvestasikan. Ketiga bagaimana mendanai keperluan serta investasi tersebut dilakukan. Untuk itu bumdes perlu mencari sumber dana untuk membiayai kebutuhan operasional. Dalam suatu bumdes pengaturan kegiatan keuangan sering disebut sebagai perencanaan dan pengelolaan keuanngan atau manajemen keuangan. (Suad Husnan, 2012).

Perencanaan dan Pengelolaan keuangan menyangkut kegiatan perencanaan keuangan, analisis keuangan dan pengendalian kegiatan keuangan. Orang yang melakukan kegiatan tersebut dikenal sebagai manajer keuangan. Kegiatan praktik akuntansi dan pengelolaan keuangan dapat dikelompokkan menjadi dua kegiatan utama, yaitu kegiatan menggunakan dana dan pencarian dana, serta pencatatan yang harus dilakukan. Dana yang diperoleh kemudian diinvestasikan pada berbagai keperluan perusahaan, untuk mendanai kegiatan perusahaan. Dari kegiatan menanamkan dana, perusahaan mengharapkan untuk memperoleh hasil yang lebih besar dari pengorbanannya. Dengan kata lain diharapkan diperoleh laba. (Suad Husanan, 2012).

Perencanaan dan Pengelolaan keuangan yang dilakukan oleh seorang manajer keuangan adalah harus mengambil keputusan tentang bagaimana peggunaan dana, memperoleh dana serta kegiatan pembagian laba. Ketiga kegiatan tersebut merupakan keputusan yang harus dilakukan oleh manajer keuangan. Keputusan investasi akan tercermin pada sisi aktiva perusahaan. Dengan demikian akan mempengaruhi struktur kekayaan bumdes, yaitu perbandingan antara aktiva lancar dengan aktiva tetap. (Suad Husnan, 2012).

Untuk melaksanakan perencanaan dan pengelolaan keuangan dengan baik perlu dipahami bagaimana perencanaanyang sesuai dengan kaidah perencanaan yang dilakukan dan manajemen keuangan. Pemahaman perencanaan dan teori keuangan tersebut bukan hanya berguna bagai manajer keuangan yang bertanggung jawab dalam bidang keuanga suatu bumdes atau organisasi, tetapi juga untuk individu dan masyarakat secara keseluruhan dalam kehidupan sehari- hari. Pemahan perencanaan dan teori keuangan akan memudahkan bagi pengelolaan keuangan, memudahkan untuk memehami berbagai masalah keuangan yang dihadapi dalam kehidupan sehari-hari bumdes, karena masalah keuangan merupakan masalah rill yang menarik untuk dipecahkan atau diselesaikan dalam kegiatan bumdes. 
Bumdes diharapkan dapat menjadi tulang punggung pembangunan ekonomi masyarakat desa, jumlah Bumdes tercatat sebanyak 1399 unit dan jumlah yang aktif dalam tahun 2019 di Jambi mecapai 722 unit atau berkisar 51,61\%. Berdasarkan uraian tersebut di atas maka untuk bisa mengelola Bumdes dengan baik, maka salah satunya diperlukan perencanaan dan pengelolaan keuangan dengan baik.

Desa Mendalo Darat, Kecamatan Jambi Luar Kota, Kabupaten Muaro Jambi adalah merupakan suatu desa di Kabupaten Muara Jambi, yang terletak di Desa Mendalo Darat, yang sangat strategis dilingkungan 2 kampus Universitas yang terbesar di Muaro Jambi, yaitu Kampus Universitas Jambi dan Kampus Universitas Islam Negeri Sultan Taha, Jambi. Bumdes diharapkan dapat tumbuh dan berkembang ditempat yang straategis ini. Guna menjalankan kegiatan usahanya, Bumdes memerlukan dana, bagaimana mendapatkan dana dan bagaimana pengelolaan dana untuk itu diperlukan perencanaan dan pengelolaan keuangan yang profesional dalam bentuk pengambilan keputusan yang benar. Perumusan masalah kegiatan pengabdian iini adalah sebagai berikut: Kemampuan Bumdes dalam mengembangkan usaha tentunya tidak terlepas dari kemampuan melakukan perencanaan dan mengelola keuangan perusahaan. Kemampuan mengembangkan usaha bila tidak diimbangi dengan kemampuan membuat perencanaan dan pengelolaan keuangan yang memadai dan baik akan mengganggu kelancaran operasional perusahaan. Hal ini menyangkut pada kurangnya SDM yang terampil dalam memahami dan melaksanakan perenccanaan dan pengelolaan keuangan.

Tim Pengabdian Kepada Masyarakat, Jurursan Akuntansi, Fakultas Ekonomi dan Bisnis, Universitas Jambi, akan menyelenggarakan kegiatan pelatihanmenysun perencanaan dan pengelolaan keuangan BumDes, dalam upaya meningkatkan kinerja BumDes di Desa Mendalo Darat Khalayak Sasaran Khalayak sasaan yang diundang dalam kegiatan pelatihan perencanaan dan pengelolaan keuangan adalah seluruh pengelola BUMDes dan perangkat desa, serta stake holder BUMDes di Desa Mendalo Darat, Masyarakat dan Mahasiswa serta berbagaii pihak yang berkepentingan di Desa Mendalo Darat, Kecamatan Jambi Luar Kota, Kabupaten Muaro Jambi, berjumlah 30 orang. Penetapan khalayak sasaran ini merupakan upaya untuk peningkatan pemahaman dalam menyusun perencanaan dan pengelolaan keuangan BUMDes

Berdasarkan latar belakang tersebut di atas maka dapat diidentifikasi masalah pengabdian sebagai berikut: (1) Bagaimanakah praktik perencanaan keuangan dan pengelolaan keuangan, ( Penjualan, Produkdsi, biaya, Kas, Piutang dan Persediaan) di dalam usaha yang dilakukannya? (2) Bagaimanakah perencanaan dan pengelolan keuangan dapat memberikan dampak terhadap kegiatan penjualan, produksi, biaya, pemasaran, dan kegiatan kinerja Bumdes secara keseluruhan.

\section{TARGET DAN METODE PELAKSANAAN}

Pengabdian pada masyarakat yang akan dilakukan diawali dengan melakukan kegiatan pendahuluan yang ditujukan untuk memperoleh informasi awal mengenai obyek (BumDes) tempat kegiatan yang akan dilakukan di Desa Mendalo Darat, tahap pendahuluan meliputi kegiatan:

Tahap perencanaan, pada tahap ini tim pengabdian Mengidentifikasi persoalan perencanaan penjualan dan pengelolaan BumDes, Mengidentifikasi sumber daya yang dimiliki oleh desa. Selanjutnya pada tahap ini tim membuat perencanaan dengan menyusun berbagai kegiatan dan keperluan yang dibutuhkan untuk kegiatan pengabdian yang akan 
dilakukan seperti meninjau lokasi pengabdian, menyiapkan materi pengabdian serta menetapkan nara sumber yang akan melakukan kegiatan.

Tim selanjutnya melakukan kunjungan ke lapangan, ke Desa Mendalo Darat, guna mengumpulkan informasi dan menyiapkan segala yang diperlukan selama kegiatan pengabdian dilakukan, sehingga kegiatan yang direncanakan dapat berjalan dengan lancar.

Kegiatan pengabdin dilaksanakan secara terprogram dan memerlukan waktu lebih kurang 2 hari. Adapun rencana kegiatan yang dimaksdukan adalah sebagai berikut: Survei penentuan lokasi pengabdian dan persiapan, penyusunan rencana kegiatan, menyiapkan materi, persiapan pelaksanaan, pelaksanaan kegiatan, dan dan sosialiasi tentang pentingnya perencanaan dan pengelolaan keuangan, menysusun program konsultasi dan pendampingan serta penyusunan laporan kegiatan pengabdian yang telah dilakukan.

Metode kegiatan pengabdian yang direncakan akan dilakukan dalam bentuk ceramah dan berdiskusi dan dilengkapi dengan audio dan power point. Ceramah dan simulasi dilakukan dengan cara menjelaskan bagaimana seharusnya sebuah BumDes menyusun kegiatan perencanaan dan pengelolaan keuangan dengan baik. Ceramah yang dilakukan juga disertai dengan contoh-contoh yang terkait dengan bagaimana seharusnya menyusun perencanaan keuangan dan pengelolaan keuangan yang baik dilakukan.

Metode ceramah dilanjutkan dengan mengadakan diskusi dan simulasi dengan pengurus BumDes dan peserta, sehingga dengan berdiskuasi diharapkan peserta mendapatkan informasi yang lengkap mengenai bagaimana seharusnya perencanaan keuangan dibuat dan pengelolaan keunagan itu dilakukan. Dengan perencanaan dan pengelolaan keuangan yang baik BumDes diharapkan akan bisa meningkatkan produktivitas serta berkembang lebih maju dan terjadi peningkatan kinerja BumDes..

\section{PEMBAHASAN}

\section{Pentingnya Pembangunan BUMDes di Kabupaten Muaro Jambi.}

BUMDes didirikan dan diatur berdasarkan UU No. 6 Tahun 2014 tentang Desa. Hal ini dijelaskan secara eksplisit dalam pasal 87 ayat (1) sampai (3) yang menyebutkan bahwa Desa dapat mendirikan Badan Usaha Milik Desa, yang dikelola dengan semangat kekeluargaan dan kegotongroyongan, dan dapat menjalankan usaha di bidang ekonomi dan/atau pelayanan umum sesuai dengan ketentuan peraturan perundang-undangan.

BUMDes sendiri didefenisikan sebagai badan usaha yang seluruh atau sebagian besar modalnya dimiliki oleh Desa melalui penyertaan secara langsung yang berasal dari kekayaan Desa yang dipisahkan guna mengelola aset, jasa pelayanan, dan usaha lainnya untuk sebesar-besarnya kesejahteraan masyarakat Desa.

Perhatian pemerintah tentang Desa khususnya terhadap BUMDes ditindaklanjuti dengan dikeluarkannya Peraturan Pemerintah No. 47 Tahun 2015 dan Permendagri No. 39 Tahun 2010 tentang BUMDes. Berbagai kebijakan tersebut menandakan keseriusan pemerintah dalam mengembangkan BUMDes. Kepemilikan lembaga BUMDes ini dikontrol bersama dimana tujuan utamanya untuk meningkatkan standar hidup ekonomi masyarakat. BUMDes lahir sebagai suatu pendekatan baru dalam usaha peningkatan ekonomi Desa berdasarkan kebutuhan dan potensi Desa.

Pengelolaan BUMDes sepenuhnya dilaksanakan oleh masyarakat Desa, yaitu dari Desa, oleh Desa, dan untuk Desa. Cara kerja BUMDes adalah dengan jalan menampung kegiatan-kegiatan ekonomi masyarakat dalam sebuah bentuk kelembagaan atau badan usaha yang dikelola secara profesional, namun tetap bersandar pada potensi asli Desa. Hal ini dapat menjadikan usaha masyarakat lebih produktif dan efektif. Kedepan BUMDes akan berfungsi sebagai pilar kemandirian bangsa yang sekaligus menjadi lembaga yang menampung kegiatan ekonomi masyarakat yang berkembang menurut ciri khas Desa dalam rangka meningkatkan kesejahteraan masyarakat Desa. Pengembangan 
BUMDes perlu juga dilakukan agar BUMDes yang telah berdiri dapat berfungsi sesuai dengan peranannya. Tujuan dan sasaran BUMDes dapat tercapai jika BUMDes dikelola secara terarah dan profesional. BUMDes diharapkan merupakan solusi atas permasalahan-permasalahan yang terjadi di Desa. BUMDes diharapkan juga dapat mendorong dan menggerakkan perekonomian Desa. Keberadaan BUMDes dapat membantu pemerintah dalam mengelola potensi Desa yang kreatif dan inovatif, sehingga dapat membuka lapangan kerja baru dan dapat menyerap tenaga kerja di pedesaan. Dalam prakteknya belum semua Desa di Kabupaten Muaro Jambi memiliki BUMDes. Beberapa desa yang memiliki BUMDes tersebut legalitasnya belum kuat karena tidak dikukuhkan melalui suatu Peratauran Desa (Perdes). Sebagian besar BUMDes tersebut didirikan tahun 2015 dan 2016 sebagai respon terhadap peluang pemanfaatan Dana Desa (DD).

Pemerintah sepakat penyaluran Dana Desa pada 2020 dijalankan sesuai PMK No. 205/PMK.07/2019. Alokasi untuk dana desa dari Anggaran Pendapatan dan Belanja Negara tahun 2020 jumlahnya mencapai Rp72 triliun dengan rata-rata per Desa memperoleh sebesar Rp 960 juta. Motivasi pendirian BUMDes karena semata mengharapkan dana desa tanpa membangun sebuah mekanisme yang baik dan menjamin perputaran modal yang menguntungkan akan berpotensi menimbulkan ketergantungan baru masyarakat Desa kepada pemerintah atau bertolak belakang dengan ide awal untuk meningkatkan kemandirian Desa. Resiko lainnya adalah munculnya penyelewengan dan penyusutan dana Desa yang akan menimbulkan konflik sosial serta permasalahan hukum di kemudian hari.

Berdasarkan kondisi tersebut, dibutuhkan untuk membangun Model Perencanaan Keuangan dan pengelolaan BUMDes guna meningkatkan inovasi dan kemandirian masyarakat di Kabupaten Muaro Jambi, khususnya Desa Mendalo Darat. Pengabdian yang dilakukan ini diharapkan dapat melahirkan beberapa gagasan dan rekomendasi untuk menjadikan BUMDes sebagai lembaga desa yang mampu menysusun rencana keuangan dan pengelolaan keuangan yang mandiri dan berorientasi profit/keuntungan dengan menggali potensi yang ada di desa bersangkutan.

\section{Pelaksanaan Kegiatan Pengabdian Pada Masyarakat.}

Tim Pengabdian Pada Masyarakat Program Magister Ilmu Akkuntansi, Pascasarjana, Universitas Jambi telah melakukan kegiatan yang bertempat di Kantor Kepala Desa, Desa Mendalo Darat, Kecamatan Jambi Luar Kota. Kegiatan dilaksanakan dalam bentuk ceramah disertai dengan diskusi bersama dengan seluruh perangkat BUMDes serta perangkat desa. Diskusi terkait dengan bagaimana menyususn sebuah perencanaan keuangan serta diskusi juga dilanjutkan bagaimana sebaiknya pengelolaan keuangan dilakukan.

Perencanaan keuangan pada tahap awal dilakukan dengan menyusun perencanaan penjualan yang sudah ditetapkan oleh BUMDes untuk satu tahun kedepan. Diskusi diikuti dengan pemberian contoh bagaimana sebuah perencanaan keuangan disusun. Setelah rencana penjualan disusun dilanjutkan dengan menysusun perencanaan produksi, perencanaan kebutuhan bahan baku, perencanaan kebutuhan biaya tenaga kerja, perencanaan biaya overhead serta perencanaan kas.

Pengelolaan keuangan yang baik haruslah dilakukan sebagai berikut: BUMDes harus membuat dan menysusun pembukuan dengan baik, berikutnya yang harus dilakukan adalah membuat rencana.penggunaan uang dengan memperhatikan aspek sumber dana dan digunakan untuk apa. Berikutnnya perencanaan kas harus dibut secara efektif, tidak ada uang kas yang menganggur, dan diperlukan pengawasan terhadap aset BUMDes, hutang dan modal. Selanjutnya diperlukan perencanaan pengembangan usaha dari keuangan yang diperoleh. Kegiatan dilakukan bersamaan dengan Tim dari Jurusan Akuntansi, Fakutas Ekonomi dan Bisnis, Universitas Jambi.

\section{Respon Peserta dan Harapan.}

Pengelola BUMDes Desa Mendalo Darat yang menjadi sasaran dari kegiatan pengabdian yang dilakukan memberikan respon yang sangat baik dari kegiatan yang dilakukan. Salah satu 
indikasinya dapat dilihat dan ditunjukan dari jumlah peserta yang hadir dalam kegiatan daftar hadir), selama kegiatan pengabdian dilakukan banyak dilakukan diskusi-diskusi serta tanya jawab yang diajukan oleh peserta. Pengelola BUMDes memberikan respon dan mempunyai keinginan yang besar untuk dapat membuat perencanaann dan pengelolaan keuangan yang baik.

Tanya jawab dan diskusi yang telah dilakukan dengan pengelola BUMDes, Tim dapat menarik kesimpulan bahwa perencanaan keuangan dan pengelolaan keuangan belum dilakukan dengan baik. Hampir seluruh kegiatan yang dilakukan lebih banyak bersifat insidentil, belum ada recana penjualan dan rencana-rencana lain yang dibuat, baik itu bersifat bulanan, triwulan, semesteran atau tahunan. Pengelola belum melakukan pngelolaan karena belum memiliki pengetahuan untuk dapat membuat perencanaan dan pengelolaan keuangan dengan baik. Pengelola sangat membutuhkan pendampingan untuk dapat menyusun perencanaan dan pengelolaan keuangan dengan baik.

\section{Kesimpulan}

\section{KESIMPULAN DAN SARAN}

Kegiatan pengabdian yang telah dilakukan diharapkan dapat memotivasi seluruh pengelola BUMDes dan aparat pemerintah desa untuk meningkatkan kinerjanya, sehingga dapat meningkatkan peranan BUMDes sebagai organisasi ekonomi dan sosial di dalam pembangunan masyarakat desa, sehingga pada akhirnya BUMDes dapat membantu meningkatkan kesejahteraan masyarakat desa.

Perencanaan keuangan yang baik diperlukan untuk meningkat kinerja BUMDes secara keseluruhan. Untuk itu diperlukan penyusunan, perencanaan penjualan, perencanaan produki, perencanaan biaya produksi, perencanaan biaya bahan baku, perencanaan biaya tenaga kerja langsung, perencanaan biaya overhead pabri, dan perencaan kas. Pengelolaan keuangan harus dilakukan dengan baik.Untuk dapat membuat pengelolaan keuangan dengan baik harus dmulai dengan penyusunan pembukuan dengan baik, membuat perencanaan penggunaan kas, sehingga tidak ada uang kas yang menganggur, diperlukan pengawasan terhadap assets BUMDes. Diperlukan perencanaan, pengembangan usaha dari keuangan yang diperoleh.

\section{Saran-saran}

Pengelola BUMDes disarankan untuk membuat perencanaan keuangan dengan baik. Perencanaan keuangan untuk seluruh kegiatan yang dilakukan. Perencanaan penjualan, dan perencaan kegiatan lainnya yang dibutuhkan. Pengelola BUMDes disarankan untuk melakukan pengelolaan keuangan untuk pengembangan usaha yang dijalankan. Lembaga Pengabdian Kepada Masyarakat Universitas Jambi disarankan untuk membuat program pendampingan yang terjadwal terhadap berbagai pihak yang memerlukan bantuan. Seperti BUMDes, dan pihak lainnya. 


\section{DAFTAR PUSTAKA}

J.F. Weston dan EF Bringham, 2010. Essentials of Managerial Finance, The Dryden Press Hinsdale Illinois.

J.C. Van Horne. 2012. Financial Management and Policy. Prentice Hall of India Private Limited, New Delhi.

Prasetyo,Randy.2014.Diunduh https://blog.ub.ac.id/randyprasetyo/2014/11/06/ke uanganpublik/

Perermendes PDTT No. 4 Tahun 2015 SAI 2014. Diunduh : http://sgoldberjangka.com/pentingnya-perencanaan-finansial-perusahaan-untuk-mengaturkeseimbangan-dana-perusahaan/

Suad Husnan, 2012. Manajemen Keuangan. Buku 1. BPFE UGM Yogykarta.

Suad Husnan, 1997. Manajemen Keuangan. Buku 2. BPFE UGM Yogyakarta. Supriadi. Diunduh: https://biizaa.com/mengenal-jenis-anggaran-dalam-badan-usaha-milik-desa/ Senduk, Safir. 2009. Mengelola Keuangan Keluarga. Jakarta: PT. Elex Media Komputindo. 